Characteristics necessary in types suitable for continuous wearing have necessitated a compromise in design between degree of protection and acceptability to the wearer. A review of the standard of protection demanded will sometimes result in a very much more wearable device.

Mr. Whittaker emphasized the importance of a good fit of face-pieces, which is easier to secure with full-sized face masks, going under the chin, than with the small kind covering only the mouth and nose. The larger the protective appliance, however, the greater is the aversion to wearing it and the risk of its being surreptitiously discarded. Discipline in the atomic energy field in this respect is better than in older industries because the workers are well aware of the danger and are accustomed to imperceptible risks.

The second section of the conference consisted of papers on the protection of the skin by Prof. J. R. Squire, of the Department of Experimental Pathology, University of Birmingham, and by Dr. A. Lloyd Potter, of the General Chemicals Division, Imperial Chemical Industries, Ltd. Prof. Squire described how the outer layer of the skin is chemically inert but swells in alkalis and, being a protein, can react with or absorb substances containing $-\mathrm{NH}_{2}$ or $-\mathrm{SH}$ groups. It can be destroyed by reducing agents and eracked if dried excessively. Loss of water is normaily impeded by a surface film of fatty material which is replenished naturally after removal with solvents in about two hours. Mechanical abrasion, leading to wear of the horny surface faster than the germinal layer can replace it, is occasionally encountered in industry. Chemical irritants produce their effect rapidly when they act as sensitizers, in which case an intense reaction may follow a second exposure, even to very small quantities, after an interval of ten to fourteen days. Carcinogens require years to produce even precancerous effects, and the peak incidence of skin cancer is twenty to thirty years after exposure. Repeated exposure is necessary, and the action decreases when less of the carcinogen reaches the skin.

Dr. Lloyd Potter said that in order to affect the skin a substance must wet it, either by being itself liquid or by solution in perspiration or other liquid. Water, alcohol and weak acids do not greatly affect the skin; but alkalis and fat solvents penetrate to the sebaceous layer. Liability to dermatitis is not detectable at pre-employment medical examinations. Protection of a process by complete enclosure may be nullified if the final product is packed by hand. Protective clothing should not add to the risk of contracting dermatitis by causing sweating and chafing. Proper washing facilities should be provided for and used by workers, and, in this connexion, barrier creams are good because they encourage washing.

Speakers in the afternoon session were introduced by Sir Harold Roberts (chief inspector of mines), who stated that mining is the most dangerous of industries, being closely followed by shipping in respect of fatalities. The death-rate in coal mining is nine times as high as the death-rate in factories, major catastrophies being responsible for only a very small proportion of the casualties in mines; the major toll is taken by falls of ground and by transport opera. tions. Owing to improved standards of lighting, the incidence of nystagmus has been greatly reduced.

Dr. D. R. Campbell, director of research, Birming ham and Midland Eye Hospital, in a paper on ocular injuries and hazards, said that eye injuries constitute 4.26 per cent of all industrial accidents and are mostly preventable, being due to flying particles. Goggles are liable to steam up ; they restrict vision and are uncomfortable to wear. They are better received if the worker is given a number of kinds to choose from. Ocular injuries are often repairable, now that the complication of infection is largely absent, but even a small scar on the centre of the cornea can cause dazzle in artificial light. Eye protection, she said, should be compulsory when striking and chipping with metal tools. Burns from molten metals and chemicals, especially caustic soda, are dangerous, though immediate irrigation with water may save an eye.

The legal obligation to provide eye protection against certain hazards was then explained by G. V. Thom, safety officer, Plastics Division, Imperial Chemical Industries, Ltd. Protection built in to a machine is more desirable than protecting the operator, and he showed typical examples. Various devices for personal eye protection were described. In the particular case of welding, protection against infra-red rays is needed, and against ultra-violet as well in electric-arc welding.

H. Bradley, director of the British Boot and Shoe and Allied Trades Research Association, was the first speaker in the session on the protection of the feet, and outlined the steps which have led to the drafting of British Standards for safety footwear. These contain a steel toe-cap which has to resist an impact test. He was followed by H. E. Thomas, head of the Safety Department of the Ford Motor Company, who said that, in his experience, the standard safety boot did, in some cases, give protection but that many toe fractures while wearing them continue to arise. $\mathrm{He}$ thought these could be avoided by extending the too-cap backwards. It is true that it would then be unable to pass the impact test, but it is evident that considerable deflexion of the toe-cap is possible without injury to the wearer's foot.

C. N. Davies

\section{THE FUNCTION OF LIBRARIES}

$A$ $T$ the annual conference of the Library Association, held in Southport during September 20-23, two speakers concerned themselves particularly with the university library. Sir Philip Morris, in his presidential address on September 20, drew on his experience in visits to universities overseas since the Second World War, when he found that there was no university which was not either replanning or developing its library, designing a new library and library service, or had just completed some new library undertaking. In Canada and the United States last year he saw, and discussed with those responsible for, five large new libraries completed within the past two or three years. All were different, and while there appeared to be no single answer to the problem of library design, the physical environment, arrangement and facilities of a library profoundly affected its service, and there appeared to be a growing need for much more co-operation and interdependence between libraries. Sir Philip believes that the efficiency of a university might be said to be a function of the adequacy and efficiency of its libraries, and, apart from this factor of co-operation, he emphasized the importance of books being avail- 
able in suitable circumstances for the reader, and especially the importance of high standards of education and professional ability on the part of the library staff.

These points were elaborated more fully later at the conference by Dr. L. W. Sharp in a paper entitled "What do we look for in a University Library ?" Dr. Sharp said little of library co-operation, believing it to be in a very healthy state so far as university libraries are concorned. He referred, however, to some of the difficulties occasioned by departmental libraries and made some suggestions for co-operation here in regard to book selection, exhibits and the like. Like Sir Philip Morris, he stressed the supreme importance of the quality of the library staff, referring to the importance of a university librarian having othor academic interests and of encouraging his assistants to widen their interests, for example, through exchanges of staff with other libraries at home and abroad and by the provision of more research scholarships for special library projects. On the subject of library design, he emphasized, like Sir Philip, the importance of having regard to individual circumstances, as well as to the needs of the reader, and commended specially the provision of some rooms for special collections. He stressed particularly the principle that the university library is equally for masters and scholars, and that students should have as free access as any other readers. He does not think that the division into a scholars' library and a masters' library, from which scholars are excluded, is sound; the aim should be to let the student feel that he is a member of a scholarly community and that he is welcome and his place is honourable.

Among the other papers presented to the conference, three were of particular interest to the scientist. They dealt with the general theme, "The Library in the Community", that of Mr. W. S. Haugh (city librarian, Bristol) reviewing the public library service in general. Mr. Haugh said that only fifteen English municipal authorities serving populations in excess of a hundred thousand exceeded $1 s, 6 d$. per head of population in their expenditure on books during 1952-53, whereas nine spent less than $10 d$. per head as against the $2 s$. suggested as standard in the centenary assessment brochure. For the counties later figures are available, and seven English county authorities are estimated to exceed $2 s$. per head in 1955-56 and seven others to be spending less than 1s. 3d. Of more specific interest to the scientific worker and technologist, however, were Mr. Haugh's observations on the importance of adequate expenditure on books in the schools and its bearing on educational efficiency, and what is being done by county libraries and other public library services to improve the facilities for educational reading for children as well as for students of technology and of other subjects. He referred particularly to some recent developments in the provision of technical information services by the public libraries, such as the scheme at Liverpool that provides for an immediate temporary technical library and a permanent technical library at a cost of $£ 270,000$; the establishment of technical library facilities at the Speke Branch Library serving the trading estate there, as well as branch technical libraries elsewhere; the extension of the Leeds commercial and technical library; the establishment of a separate technical department at Rugby; and the formation at Luton, where the central library maintains a large file of information on the requirements of the export trade, of the Luton and District Technical Information Service. He also mentioned the installation earlier this year in the Manchester Central Library of a teleprinter apparatus giving a direct link to more than a hundred users in the Manchester area, two thousand in the United Kingdom and twenty-five thousand in twenty-one centres abroad, and to the formation of co-operative industrial and commercial reference and information services among public libraries and business firms both in the West London and the North London areas.

Of the other two papers, Mr. H. Thompson (technical librarian, Lancashire County Library), dealing with technical library services in the county, described more particularly the nature of this service, emphasizing its bearing on technical education, and the importance both of mobility and of taking full account of the various requirements of the groups served. Mr. D. J. Foskett (librarian and information officer of the Metal Box Co., Ltd.), dealing with special libraries, also referred to co-operation in the technical field, and his paper was particularly valuable for emphasizing the necessity in all such schemes of remembering that the special library owes its first responsibility to the group by which it is maintained. If this is ignored, the special library can scarcely make its contribution either in co-operation or in the development of new techniques and improved services.

\section{ROTHAMSTED EXPERIMENTAL STATION REPORT FOR 1954}

$\mathrm{W}$ ITH the advent of any new agricultural problem that is amenable to scientific treatment, it has become almost a matter of course for the interested parties to ask: "What is Rothamsted doing about it ?" Clearly it is impossible for any research station to follow up too many of the problems of the moment without dangerous dispersal of effort and neglect of fundamental aspects. It is therefore heartening to see that the annual report of the Rothamsted Experimental Station (Pp. 242, 7s, 6d., from Rothamsted Experimental Station, Harpenden) again reflects a most satisfactory balance between pure and applied research and in the choice of the problems being studied. It is also clear from the very large number of visitors from all parts of the world that the Station continues to play a vital part in the exchange of information.

In the Physics Department there have been further advances in the techniques for measuring microclimates, and these methods are being used to study the conditions affecting the spread of virus diseases and of blight in potatoes. A new sodium-saturation test has been used to assess the increase in crumb cohesion caused by certain high polymers. It is interesting to note that some of these are more effective on acid than on calcareous soils. Work continues on the crystal structure of kaolinite.

Notable among a wide range of studies in the Chemistry Department are experiments on the placing of fertilizers. It has been demonstrated that some crops, including potatoes, benefit from the placing of nitrogen and potassium as well as phosphorus. Important progress has been made in the estimation of ammoniacal and nitrate nitrogen in soils, and fundamental studies are being made of 